\title{
EKSISTENSI PEKERJA SOSIAL DI INDONESIA, MALAYSIA DAN AMERIKA SERIKAT
}

\author{
Adetya Nuzuliani Rahma, R.Nunung Nurwati, Budi Muhammad Taftazani
}

(Email: Adetya.nuzuliani@gmail.com)

\begin{abstract}
ABSTRAK
Dengan masyarakat sejahtera di dalam suatu negara, dapat dijadikan indikator negara tersebut maju atau berkembang. Sehingga kesejahteraan sosial menjadi salah satu indikator yang penting dalam pembangunan suatu negara. Berbicara mengenai kesejahteraan sosial, sangat erat kaitannya dengan profesi pekerjaan sosial. Pekerja sosial dengan keterampilan, nilai-nilai, dan metode serta pendekatan yang dimilikinya mampu meningkatkan keberfungsian sosial individu, keluarga, masyarakat, sehingga dapat meningkatkan kesejahteraan sosial suatu negara. Dengan demikian keberadaan profesi pekerjaan sosial penting dan berpengaruh terhadap kesejahteraan suatu negara.

Dalam tulisan ini, penulis menggambarkan profesi pekerjaan sosial di beberapa negara, seperti Indonesia, Malaysia, dan Amerika Serikat dengan tujuan untuk memberikan informasi, gambaran umum dan pengetahuan mengenai eksistensi pekerja sosial di masing-masing negara. Selain itu, dari informasi-informasi tersebut dapat dijadikan rujukan untuk meningkatkan eksistensi pekerja sosial di Indonesia.
\end{abstract}

Kata Kunci : kesejahteraan sosial, pekerjaan sosial, 


\section{PENDAHULUAN}

Kesejahteraan sosial suatu negara erat kaitannya dengan pembangunan negara tersebut. Kesejahteraan sosial dapat dijadikan sebagai indikator negara tersebut maju atau masih berkembang. Edi Suharto (2007:1) dalam tulisannya yang berjudul Paradigma Ilmu Kesejahteraan Sosial mengungkapkan bahwa kesejahteraan sosial dapat diartikan sebagai pendekatan atau kegiatan yang terorganisir dalam bidang pembangunan sosial.

Di Indonesia, kesejahteraan sosial sering dipandang sebagai tujuan atau kondisi kehidupan yang sejahtera, yakni terpenuhinya kebutuhan pokok manusia (Suharto, 2006a;2006b).

Menurut Wibhawa Budhi, dkk,(2010:23-25), di dalam bukunya yang berjudul Dasar-dasar Pekerjaan Sosial, konsep kesejahteraan dapat dilihat dari empat sisi, sebagai berikut :

a. Sebagai system pelayanan sosial Elizabeth Wickenden mendefinisikan kesejateraan sosial sebagai :

"a system of laws,programs, benefits, and services which strengthen or assure provision for meeting social needs recognized as basic for the welfare of the population and for the functioning of the social order."

Dari definisi di atas menjelaskan bahwa konsep pelayanan sosial mencakup perundangan-undangan sampai pemberian bantuan secara langsung, konsep kebutuhan sosial yang merupakan dasar dalam kesejahteraan sosial, dan tujuannya ialah mencapai keberfungsian sosial.

b. Sebagai suatu disiplin keilmuan

Menurut Wibhawa Budhi, (2010:25) mengemukakan sebagai berikut :
Konsep kesejahteraan sosial dipandang sebagai sebuah bidang kajian keilmuan yang ditujukan untuk mengkaji, mengantisipasi keadaan, dan perubahan kehidupan sosial, serta merumuskan alternatif tindakan guna menciptakan situasi kehidupan sosial yang kondusif bagi upaya warga masyarakat dalam memenuhi kebutuhan-kebutuhan hidupnya sendiri.

Dari definisi diatas, ilmu kesejahteraan sosial berupaya mengembangkan dasar pengetahuannya untuk mengidentifikasi masalah sosial, penyebab dan strategi penanggulangannya untuk kehidupan masyarakat suatu negara agar menjadi lebih baik.

Menurut Edi Suharto dalam tulisannya yang berjudul Paradigma Kesejahteraan Sosial mengemukakan bahwa pada masa awal perkembangannya, kesejahteraan soisal memiliki basis ilmu yang dikembangkan dari berbagai disiplin ilmu sosial lain, terutama filsafat, sosiologi, psikologi, antropologi, politik, dan ekonomi.

\section{c. Sebagai suatu keadaan hidup}

Menurut Wibhawa Budhi, (2010:26), kata 'sosial' dalam kesejahteraan sosial, memiliki arti hubungan sosial. Mengacu pada kata 'sosial' tersebut, kesejahteraan sosial sebagai: "suatu keadaan hidup ialah keadaan hubungan manusia yang baik, artinya yang kondusif bagi manusia untuk melakukan upaya guna memenuhi kebutuhan hidupnya secara mandiri."

Dari definisi di atas, konsep baik dalam hubungan manusia diukur dari nilai-nilai dan norma-norma sosial di dalam masyarakat. Konsep kondusif tersebut, berarti hubungan manusia tersebut berwujud dalam tatanan sosial yang memberikan kesempatan kepada masyarakat untuk berusaha mencapai kesejahteraan hidupnya.

Kesejahteraan sosial merupakan tujuan bagi negara dimanapun. Semua negara pasti memiliki tujuan untuk menyejahterakan masyarakatnya. Manusia yang sejahtera ialah manusia yang mempunyai kemampuan 
menjalin interaksi yang baik dengan sesamanya, artinya kebahagiaan dan ketidakbahagiaan manusia terletak pada kualitas hubungannya dengan manusia lain.

Berbicara mengenai kesejahteraan sosial, maka erat kaitannya dengan pekerjaan sosial. Layaknya pendidikan berhubungan dengan guru, kesehatan dengan dokter. Maka ketika berbicara mengenai kesejahteraan sosial, maka profesi yang terlibat ialah pekerjaan sosial.

Dalam tulisan ini, penulis akan menggambarkan profesi pekerjaan sosial di beberapa negara, seperti Indonesia, Malaysia, dan Amerika Serikat.

\section{Pekerja Sosial Sebagai Suatu Profesi}

Berbicara mengenai pekerja sosial, tentunya terlebih dahulu harus mengetahui definisi pekerjaan sosial. Definisi pekerjaan sosial menurut Zastrow, Charles ialah sebagai berikut :

Pekerjaan sosial adalah aktivitas professional untuk membantu individu, kelompok, atau komunitas, guna meningkatkan atau memperbaiki kapasitasnya untuk berfungsi sosial dan menciptakan kondisi masyarakat guna mencapai tujuan-tujuannya. (dalam Wibhawa Budhi,dkk,2010:45).

Profesi dikatakan professional apabila memiliki bidang keahlian yang ditempuh melalui sekolah atau perguruan tinggi. Hal ini senada dengan Wibhawa Budhi, (2010:42),

Pekerjaan sosial sebagai sebuah bidang keahlian (profesi) yang berarti memiliki landasan keilmuan dan seni dalam praktik (dicirikan dengan penyelenggaraan pendidikan tinggi).

Dengan demikian, pekerjaan sosial berbeda dengan kegiatan sosial atau charity yang dapat dilaksanakan oleh siapapun yang memiliki kenginan untuk menolong orang lain. Para penyandang profesi pekerjaan sosial memiliki kewenangan sebagai akibat sosial dari pendidikan keahliannya, untuk menyelenggarakan pelayanan sosial dalam semua bentuk dan tingkatnya. Keahlian khusus dalam profesi pekerjaan sosial adalah manipulasi perilaku manusia (secara individual maupun dalam unit sosial), yang ditujukan untuk meningkatkan keberfungsian sosial manusia sebagai makhluk sosial.

Selain ilmu yang didapat dari perguruan tinggi, pekerja sosial dapat dikatakan sebagai profesi pekerjaan sosial, karena hal-hal berikut ini yang dikemukakan oleh Johnson dan Schwartz (1991:120) :

1. A systematic body of theory

2. Professional authority

3. Community sanction

4. Code of ethics

5. Professional culture

William Wickenden juga mengemukakan suatu bidang keahlian dikatakan sebagai profesi apabila memenuhi syarat-syarat sebagai berikut :

1. Body of knowledge

2. Proses pendidikan

3. Kode etik

4. Pengakuan status

5. Wadah atau organisasi

Kelima hal tersebut menunjukan bahwa pekerjaan sosial dapat dikatakan sebagai sebuah profesi.

\section{Nilai-nilai Dasar Pekerjaan Sosial}

Sebagai suatu profesi pekerjaan sosial memiliki nilai-nilai dasar yang dijunjung. Menurut Johnson dan Schwartz (1991 :132), nilai-nilai profesi pekerjaan sosial ialah :

1. The worth and dignity of people

Menghargai harkat dan martabat manusia seutuhnya

2. The self determination of people

Memberikan kebebasan mengambil keputusan oleh klien. Penting bagi klien untuk memilih keputusan yang tepat menurut dirinya sendiri.

3. The purposefulness of human behavior

Pekerja sosial percaya bahwa setiap tingkah laku manusia memiliki tujuan. Walaupun ada tingkah laku yang diluar 
kebiasaan, pekerja sosial tidak boleh memberikan stretotype atau label yang negative.

4. People capacity to grow and change

Menyadari bahwa setiap manusia memiliki kapasitas untuk mengembangkan dan merubah dirinya.

5. People's need for opportunity for growth and development

Membantu kebutuhan manusia yang memiliki kesempatannya untuk tumbuh dan berkembang serta berfungsi secara sosial

6. People's right to participate actively in social work practice

Pekerja sosial melibatkan klien dalam pemberian bantuan dan pengambilan keputusan

7. Confidentiality

Pekerja sosial harus menjaga kerahasiaan informasi seputar klien, isi pembicaraan dengan klien, pendapat professional lain, atau catatan-catatan kasus mengenai klien. Dengan demikian, klien akan merasa nyaman mengungkapkan masalahnya. Kerahasiaan ini merupakan bagian dari etika dalam praktik pekerjaan soisal.

Selain itu, ada beberapa penambahan dari Wibhawa, Budhi (2010:130), yakni sebagai berikut :

1. Acceptance

Prinsip ini merupakan prinsip fundamental dalam pekerjaan sosial. Pekerja sosial menunjukan sikap toleran terhadap keseluruhan dimensi klien.

2. Nonjudgemental

Pekerja sosial menerima klien dengan apa adanya tanpa disertai pemikiran atau penilaian. Maksudnya pekrja sosial menerima klien dengan segala keadaannya, menilai klien sebagai manusia dengan latar belakang sejarahnya sendiri, tidak menilai perilakunya, dan tidak memaksakan nilai-nilai yang dimiliki oleh pekerjaan sosial terhadap klien.

3. Individualisasi

Pekerja sosial memandang dan mengapresiasi sifat unik dari klien. Setiap klien memiliki karakteristik kepribadian, dan permasalahan yang unik, dan berbeda satu sama lain. Setiap individu dibentuk oleh pengalaman, kebutuhan situasi, dan pengetahuannya. Dengan demikian pekerja sosial tidak dapat menggeneralisasi persoalan yang sama pada klien yang berbeda.

Nilai-nilai tersebut dijadikan pedoman bagi pekerja sosial dalam melakukan praktik pekerjaannya.

\section{Keterampilan Pekerja Sosial}

Sebagai profesi yang professional, pekerja sosial tentunya memiliki keterampilan yang menunjang pekerjaannya. Johnson dan Schwartz (1991 :133) membagi keterampilan pekerja sosial menjadi 3 bagian yakni :

1. Interpersonal helping skills

2. Social work process skills

3. Evaluation and accountability skills.

Keterampilan dalam membangun hubungan interpersonal dengan klien ialah :

1. Keterampilan pekerja sosial untuk berkomunikasi dengan klien, keterampilan mendengarkan secara aktif,keterampilan untuk mengerti, dan menginterpretasi komunikasi klien, baik verbal maupun non verbal serta membantu klien untuk meningkatkan keberfungsian sosialnya

2. Kemampuan pekerja sosial untuk membangun kepercayaan dengan klien

3. Kemampuan wawancara atau konseling dengan menggunakan active listening dan keterampilan lainnya seperti paraphrasing, reflection of feeling, confrontation, dan sebagainya.

Keterampilan-keterampilan tersebut sangat berguna bagi pekerja sosial dalam melaksanakan peran dan tugasnya seperti mengidentikasi permasalahan klien dengan lingkungan sosialnya, menerapkan treatment, dalam menjalin hubungan dengan stakeholder-stakeholder, dan meningkatkan keberfungsian sosial klien, baik itu individu, kelompok, dan masyarakat dengan berbagai 
metode dan pendekatan yang dimiliki pekerja sosial.

\section{Metode dan Pendekatan Pekerja Sosial}

Sebagai sebuah profesi, pekerja sosial memiliki metode dan pendekatan dalam melakukan intervensi kepada klien, baik itu individu, keluarga, dan masyarakat. Metode pekerja sosial ialah sebagai berikut :

\section{Social case work}

Metode pemberian bantuan kepada orang yang didasarkan atas pengetahuan, pemahaman, serta penggunaan teknikteknik secara terampil yang diterapkan untuk membantu orang-orang guna memecahkan masalahnya dan mengembangkan dirinya. (Wibhawa Budhi,2010:97).

Metode social case work bersifat individual karenanya dikatakan pendekatan mikro yaitu membantu individu-individu yang memiliki masalah, baik yang bersifat eksternal yakni masalah yang berasal dari lingkungan sosialnya, atau masalah yang bersifat internal, atau yang berasal dari dalam dirinya sendiri.

\section{Social group work}

Suatu metode untuk bekerja dengan dan menghadapi orang-orang di dalam suatu kelompok guna peningkatan kemampuan untuk melaksanakan fungsi sosial;serta guna pencapaian tujuan-tujuan yang secara sosial dianggap baik. (Wibhawa, Budhi, 2010:99).

Pada intinya social group work ialah meningkatkan keberfungsian individu dengan bantuan kelompok.

\section{Community Organizing/ community development}

PBB (1955) mendefiniskan pengembangan masyarakat sebagai berikut :

"Pengembangan masyarakat didefinisikan sebagai suatu proses yang dirancang untuk menciptakan kemajuan kondisi ekonomi dan sosial bagi seluruh warga masyarakat dengan partisipasi aktif dan sejauh mungkin menumbuhkan prakarsa masyarakat itu sendiri." (dalam Wibhawa Budhi, 2010:109)

\section{Administrasi dan Organisasi Pelayanan} Manusia atau Sosial

John Kidneigh menyatakan bahwa administrasi pekerjaan sosial adalah

proses transformasi kebijakan sosial ke dalam pelayanan sosial melalui proses dua cara yakni transformasi kebijakan ke dalam pelayananpelayanan sosial konkrit, dan menggunakan pengalaman dengan merekomendasikan modifikasi kebijakan.

Metode atau pendekatan ini menekankan bahwa pekerja sosial tidak hanya berkonstrasi dalam individu saja namun akan menjadi perencana dan administrator programprogram pekerjaan sosial daripada bekerja dengan klien perseorangan.

\section{Pekerja Sosial di Indonesia}

Perkembangan pekerja sosial di Indonesia berawal dari nilai gotong royong masyrakat sebagai sistem pelayanan sosial. Gotong royong dianggap sebagai nilai paling dasar dalam kehidupan bermasyarakat dan bernegara. Ketika terjadi penjajahan Belanda, pemerintah Belanda memandang pelayanan sosial hanya beruapa kegiatan amal, sehingga pelaksanaannya diserahkan kepada badanbadan swasta misalnya Muhammadiyah, Nahdatul Ulama, Missi Katholik, dan sebagainya.

Pada masa penjajahan jepang, kondisi kesejahteraan masyarakat Indonesia semakin memburuk, dan lembaga-lembaga pelayanan 
sosial yang sudah dibentuk tidak berjalan sebagaimana mestinya .

Pada masa kemerdekaan, sebagai pencerminan akan pentingnya kesejahteraan sosial dan praktik pekerjaan sosial dalam bentuk pelayanan sosial, maka dibentuklah Kementrian Sosial pada 19 agustus 1945. Pada masa ini, pelayanan sosial dilakukan oleh pemerintah dan masyarakat. Sebelumnya pelayanan masyarakat dilakukan oleh masyrakat itu sendiri dengan nilai gotong royong, kemudian beralih oleh swasta pada masa penjajahan Belanda, dan setelah kemerdekaan hingga sekarang, pelayanan sosial dilakukan oleh pemerintah dan masyarakat.

Di Indonesia, kesejahteraan sosial dibahas dalam perundang-undangan. Kesejahteraan sosial merupakan suatu keadaan terpenuhinya kebutuhan hidup yang layak bagi masyarakat, sehingga mampu mengembangkan diri dan dapat melaksanakan fungsi sosialnya yang dapat dilakukan pemerintah, pemerintah daerah dan masyarakat dalam bentuk pelayanan sosial yang meliputi rehabilitasi sosial, jaminan sosial, pemberdayaan sosial, dan perlindungan sosial (UU No 11 Tahun 2009 pasal 1dan 2). Pembangunan kesejahteraan sosial ini menjadi bagian tak terpisahkan dari pembangunan nasional dimana pembangunan kesejahteraan sosial berperan aktif dalam meningkatkan kualitas hidup bangsa Indonesia. Hal ini karena pada prinsipnya konstruksi pembangunan kesejahteraan sosial terdiri atas serangkaian aktivitas yang direncanakan untuk memajukan kondisi kehidupan manusia melalui koordinasi dan keterpaduan antara pemerintah, pemerintah daerah dan masyarakat dalam upaya penyelenggaraan kesejahteraan sosial dalam mengatasi Penyandang Masalah Kesejahteraan Sosial (PMKS). Apabila dilihat dari pengertiannya, Penyandang Masalah Kesejahteraan Sosial (PMKS) merupakan seseorang, keluarga atau kelompok masyarakat yang karena suatu hambatan, kesulitan atau gangguan, tidak dapat melaksanakan fungsi sosialnya, sehingga tidak dapat terpenuhi kebutuhan hidupnya (jasmani, rohani dan sosial) secara memadai dan wajar (Dinas Sosial Provinsi DIY, 2005). Berbagai permasalahan kesejahteraan sosial yang muncul pada masyarakat Indonesia saat ini, meliputi : menurunnya tingkat ekonomi, penyimpangan norma dan perilaku, meningkatnya masalah sosial, menurunnya kualitas kesehatan, dan meningkatnya kriminalitas.

Dalam upaya mengatasi Penyandang Masalah Kesejahteran Sosial, pekerja sosial memberikan pelayanan sosial yang merupakan wujud aktivitas pekerja sosial dalam praktik profesionalnya.

Dalam artikel yang berjudul Indonesia Butuh 139 Ribu Pekerja Sosial Profesional, yang dikutip dari metrotvnews.com, menyebutkan di Indonesia, jumlah Penyandang Masalah Kesejahteraan Sosial (PMKS) ialah sebanyak 15,5 juta rumah tangga. Indonesia masih membutuhkan setidaknya 139 ribu orang pekerja sosial. Sementara saat ini jumlah pekerja sosial yang tersedia hanya sekitar 15.522 orang. Hal ini untuk memenuhi rasio ideal antara pekerja sosial dengan masyarakat yaitu 1:100. Kebutuhan akan pekerja sosial terus meningkat untuk menangani Penyandang Masalah Kesejahteraan Sosial (PMKS) tersebut. Sehingga membutuhkan jumlah pekerja sosial di berbagai bidang untuk mengatasi masalah sosial dan penyandang masalah kesejahteraan sosial di Indonesia. Sektor-sektor yang membutuhkan pekerja sosial antara lain untuk keperluan medis di rumah sakit, industri, forensik di lembaga pemasyarakatan (LP) atau badan pemasyarakatan (bapas), pekerja sosial klinis di Lembaga Rehabilitasi Sosial Korban Napza, pekerja sosial, spesialis perlindungan anak serta spesialis manajemen bencana.

Walaupun sebagian besar masyarakat masih tidak mengetahui profesi pekerjaan sosial, namun keberadaan pekerja sosial kini semakin dikuatkan dengan adanya sertifikasi kompetensi pekerja sosial dan tenaga kesejahteraan sosial. Pemberian sertifikasi difasilitasi pemerintah melalui Lembaga Sertifikasi Pekerjaan Sosial (LSPS) yang dapat menerbitkan lisensi. Lembaga 
Kesejahteraan Sosial (LKS) akan diakreditasi oleh Badan Akreditasi Lembaga Kesejahteraan Sosial (BALKS) yang akan memperkuat eksistensi profesi pekerja sosial, sekaligus menjadi landasan kebutuhan pekerja sosial profesional di Indonesia, (metrotvnews.com diakses pada Minggu 2 November 2014 pukul 10:29).

\section{Pekerja sosial di Malaysia}

Dikutip dari www.masw.org. Di Malaysia pekerjaan sosial professional diperkenalkan pada masa pemerintahan jajahan Inggris, awal tahun 1930-an. Pada masa ini, pekerjaan sosial difokuskan pada masalah buruh migran dari India dan China. Setelah Perang Dunia II, pada tahun 1946 didirikan Departemen Kesejahteraan Sosial. Awalnya pelayanan sosial yang dilakukan oleh pekerja sosial ialah dalam hal bantuan keuangan bagi yang membutuhkan, program percobaan untuk kenakalan remaja, rumah perlindungan bagi perempuan dan anak, dan perawatan untuk penyandang cacat dan lanjut usia. Pada tahun 1950 adanya spesialisasi bidang pekerjaan sosial, yaitu pekerja sosial medis dan pekerja sosial yang menangani kenakalan remaja. Pada tahun 1955 The British Almoners telah membentuk badan profesional pertama bagi pekerja sosial, Asosiasi Malayan of Almoners (MAA). Pada akhir tahun 1960 bernama Malaysian Association of Medical Social Work (MAMSW) yang berhasil diperjuangkan. Kemudian terbentuklah asosiasi pekerja sosial di Malaysia dengan nama Malaysian Association of Social Workers (MASW) yang terbentuk pada 3 Maret 1973.

Dikutip dari stks.ac.id, di Malaysia sendiri, program Magister of Medical berada dibawah fakultas kedokteran USM. Kedudukan medical social work (sebutan untuk pekerja sosial medis di Malaysia), berada dibawah divisi Public Health/Care yang merupakan secondary setting di bagian klinik kesehatan. Hingga saat ini, sekitar 250 orang medical social work - hospital telah mendapat perhatian dari pemerintah Malaysia dan mereka bekerja di klinik-klinik kesehatan yang digaji oleh pemerintah. Satu tahun terakhir ini, parlemen akan segera mengesahkan undang-undang (act) tentang standard kompetensi pekerja sosial medis yang akan memperkuat profesi tersebut.

Kondisi eksistensi pekerja sosial di Indonesia dengan Malaysia hampir mirip. Dilihat dari sejarah perkembangannya pun berdekatan, hanya berbeda beberapa tahun. Namun, jika dilihat dari pekerja sosial medis di Malaysia sudah cukup berkembang, di negaranya, dibandingkan di Indonesia.

\section{Pekerja Sosial di Amerika Serikat}

Cox (1992:40) mengemukakan : pekerjaan sosial lahir di Barat (Eropa) dan tumbuh serta berkembang di Barat (Amerika Serikat). Secara simultan, pekerjaan sosial diekspor ke negara-negara berkembang (dunia ketiga), terlepas dari kemungkinan penerapan dan relevansinya. (Wibhawa Budhi.2010:57).

Dari pernyataan di atas menunjukan bahwa, pekerja sosial telah lebih dahulu lahir dan dikenal oleh masyarakat di Amerika Serikat, dibandingakan dengan Indonesia dan Malaysia.

Dikutip dari socialworkers.org, berdasarkan data dari U.S. Department of Labor Bureau of Labor Statistics (BLS) profesi yang memiliki perkembangan yang pesat dibandingkan profesi lainnya. Lebih dari 650.000 orang memilih program atau jurusan pekerja sosial. Dengan demikian pelajar yang ingin melanjutkan pendidikannya sudah mengenal profesi pekerjaan sosial, dan mengetahui eksistensi profesi tersebut di negaranya.

Dikutip dari socialwork.org The U.S. Department of Veterans Affairs employs more than 10,000 professional social workers. It is one of the largest employers of MSWs in the United States. Dari pernyataan tersebut, di Amerika Serikat pekerja sosial sudah berkembang dan diketahui eksistensinya oleh masyarakat luas. 
Dalam situs socialwork.org pun menjelaskan eksistensi pekerja sosial dalam berbagai bidang, yakni sebagai berikut:

"Today, almost 50 special interest organizations contribute to the vitality and influence of the social work profession. There are social work groups for educators and researchers, as well as organizations for practitioners in health care leadership, nephrology, oncology, child welfare, schools, prisons, courts, and many other settings."

Di Amerika Serikat, pekerja sosial telah terspesialisasi dan telah diakui eksistensinya oleh masyarakat disana. Sehingga kini perkembangannya pesat dibandingkan negaranegara yang berkembang seperti Indonesia, dan Malaysia. Dalam melaksanakan perannya pun, pekerja sosial di Amerika Serikat telah dibagi ke dalam berbagai bidang, seperti dalam kesejahteraan anak, sekolah, kesehatan, onkologi, dan bidang lainnya.

\section{Penutup}

Perbandingan eksistensi pekerja sosial dilakukan untuk memberikan gambaran dan informasi mengenai profesi pekerja sosial di Malaysia dan Amerika Serikat. Dengan mengetahui eksistensi pekerja sosial di negara lain, dapat meningkatkan eksistensi pekerja sosial di Indonesia. Dalam hal ini, penulis memiliki beberapa saran yang dapat digunakan untuk meningkatkan eksistensi pekerja sosial di Indonesia. Adapun, saran dari penulis ialah sebagai berikut :

1. Mempublikasikan kompetensi dan kontribusi pekerja sosial dalam berbagai pembangunan sosial agar dikenal oleh masyarakat luas, misalnya dalam program-program kementrian sosial,

2. Mengembangkan pendidikan pekerjaan sosial. Misalnya, melengkapi mahasiswa dengan keahlian yang spesifik, karena spesialisasi dalam pendidikan pekerjaan sosial tampaknya semakin penting.

3. Memperkuat organisasi-organisasi profesi pekerjaan sosial Indonesia, serta meningkatkan kerjasama di tingkat nasional, regional dan internasional.

Daftar Pustaka

Johnson,Louise and Schwartz Charles.1991.Social Welfare A Response to Human Need Second Edition.Allyn and Bacon:Massachusetts Skidmore.1987.Introduction to Social Work Sixth Edition. Prentice Hall International Edition

Wibawa, Budhi, et al.2010.Dasar-dasar Pekerjaan Sosial. Widya Padjadjaran:Bandung

Suharto Edi. Peran Pekerja Sosial dalam Community Development.International Policy Fellow, Open Society Institute Central European University. Budapest, Hungary

Suharto Edi. 2007.Paradigma Kesejahteraan Sosial.

metrotvnews.com diakses pada 2 November 2014 pukul 10:29

http://www.stks.ac.id diakses pada 10 Desember 2014 pukul 14.00

www.umj.ac.id diakses pada 10 Desember 2014 pukul 14.00

http://kesos.umm.ac.id diakses pada 11

Desember 2014 pukul 11.00

http://www.masw.org.my diakses pada 12 Desember 2014 pukul 10.00

http://www.socialworkers.org diakses pada 12 Desember 2014 pukul 11.00 